\title{
DESIGNING AND BUILDING HEAVY LIFTING MODIFICATION OF A RADIO CONTROLLED HELICOPTER
}

\author{
Mikolaj Górzyński*, PrzemysŁaw Bibik** \\ * student at the Warsaw University of Technology, Faculty of Power and Aeronautical Engineering, \\ Nowowiejska Street 24, 00-665 Warsaw \\ ** Warsaw University of Technology, Institute of Aeronautics and Applied Mechanics, Nowowiejska Street 24, \\ 00-665 Warsaw \\ mikolaj.gorzynski@gmail.com, pbibik@meil.pw.edu.pl
}

\begin{abstract}
The paper presents the heavy lifting modification of radio controlled T-Rex 700 DFC PRO helicopter which was originally designed as acrobatic machine. The purpose of designing machine like this is a need for a cheap and reliable machine specifically designed to carry weights for research and development purposes. Thanks to its design there is a possibility to attach to it a measuring apparatus, modules like auto-pilot, and weights. It can be also used to test wide range of rotors and other components which makes it very universal research tool. To achieve those goals the whole frame and landing gear has been redesigned using NX 11 CAD/CAM/CAE to achieve desired cargo space and weight distribution. Additionally the tail has been lengthened to allow use of the rotors with bigger diagonal. All the applied changes has been made to increase the machine payload. The designed elements were fabricated and the helicopter has been tested in flight. During the test flights several performance parameters were measured.
\end{abstract}

Keywords: helicopter, rotor, modification.

\section{INTRODUCTION}

Nowadays on the market there is a huge need for rotor-based machines able to carry significant weights. They are used to film from the air, transport packages, by police and army for observation and even to rescue people. The most popular constructions are multi-rotor based, their advantages are stability and simplicity of steering mechanism. Control of multi-rotor based machine is achieved mainly by changing angular velocity of each rotor, which is very simple using electrical motors. In traditional single rotor helicopter the angular velocity is constant and they are controlled by 
changing pitch angle of the blades. It is much more complicated and requires mechanical swashplate but on the other hand it makes helicopter much more responsive.

Another difference is aerodynamical efficiency. From theoretical point of view single rotor construction is much more efficient than four-rotor based taking into account power/thrust ratio which has been described in „Design and Development of the Atlas Human-Powered Helicopter”[1], by makers of Atlas, first human powered helicopter that was able to meet the demands of Sikorsky prize. It's worth mentioning that Atlas has become a quadcopter because of other factors like stability and easiness and recurrence of making blades of the rotors.

The rotors they designed are perfect to achieve the best of possible thrust to power ratio so it's worth mentioning features that made them so good. They have long diameter, asymmetrical profile, variable chord, twist and very low angular velocity. All of these features are necessary to achieve great hover performance according to ideal rotor theory[2][3].

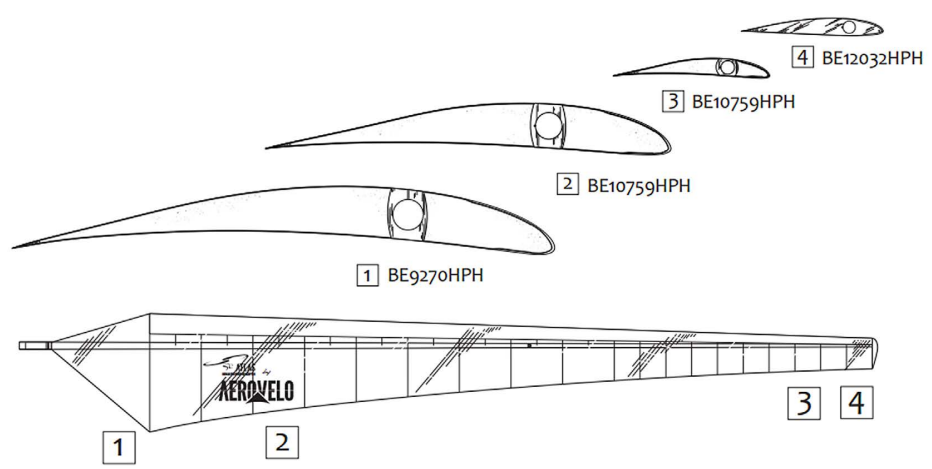

Fig. 1. Blade of the Atlas rotor.

Other features of rotor perfect to hover is number of blades which can be observed in constructions like S-64 Skycrane. Additionally it's frame is very simple, cargo space is big and due to that landing gear is very tall.

Last but not least the single rotor based helicopter is able to use autorotation in case of motor failure to land safely which is crucial when carrying valuable equipment. In multi-rotor constructions usually even one engine failure very often results in destroying machine. Moreover it's much harder to scale multi-rotor based machines due to the rotors max velocity angular speed and ability to control them, whereas one rotor based construction doesn't have such restrictions.

\section{PROJECT ASSUMPTIONS}

Due to the project time and budget restrictions it was impossible to design and built radio controlled helicopter from scratch. Instead we chose existing, off-the-shelf machine that will be modified to meet our demands. When choosing best machine we were also taking under consideration the price 
of the machine and availability of spare parts on the market so that it will be cheap in use for a long period of time. We decided to use ALIGN T-Rex 700E DFC PRO electric helicopter because of its size, reliability and wide range of upgrades available on the market.

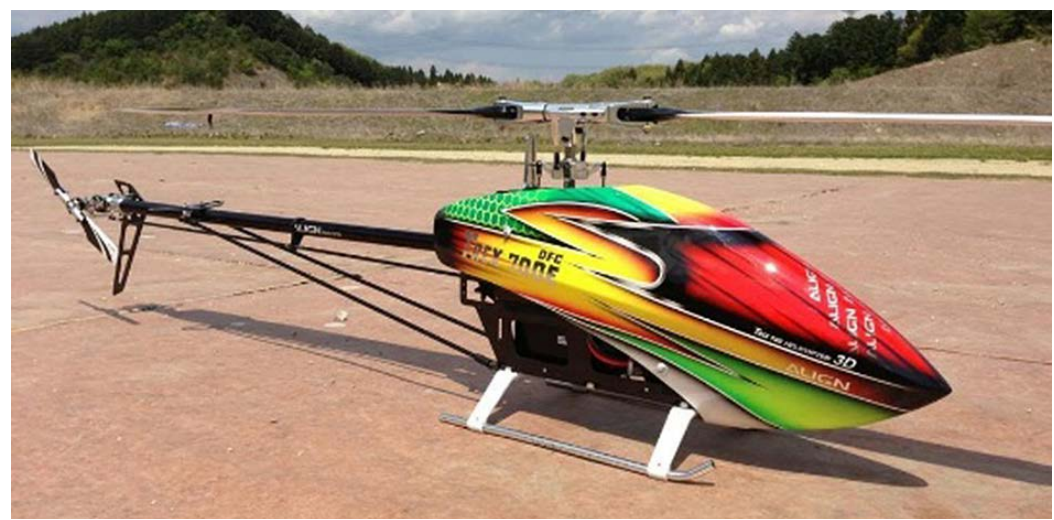

Fig. 2. T-Rex 700E DFC PRO.

Our goal was to create bigger cargo space, create dedicated place for measurement equipment and use batteries with bigger capacity for the better flight endurance. To increase hover performance we decided to increase the rotor diameter, use asymmetrical blades, increase the number of blades and lower the angular velocity of the rotor. Because of the increased performance and forces that new machine will have to deal with we also changed most of the interior components for more reliable and durable.

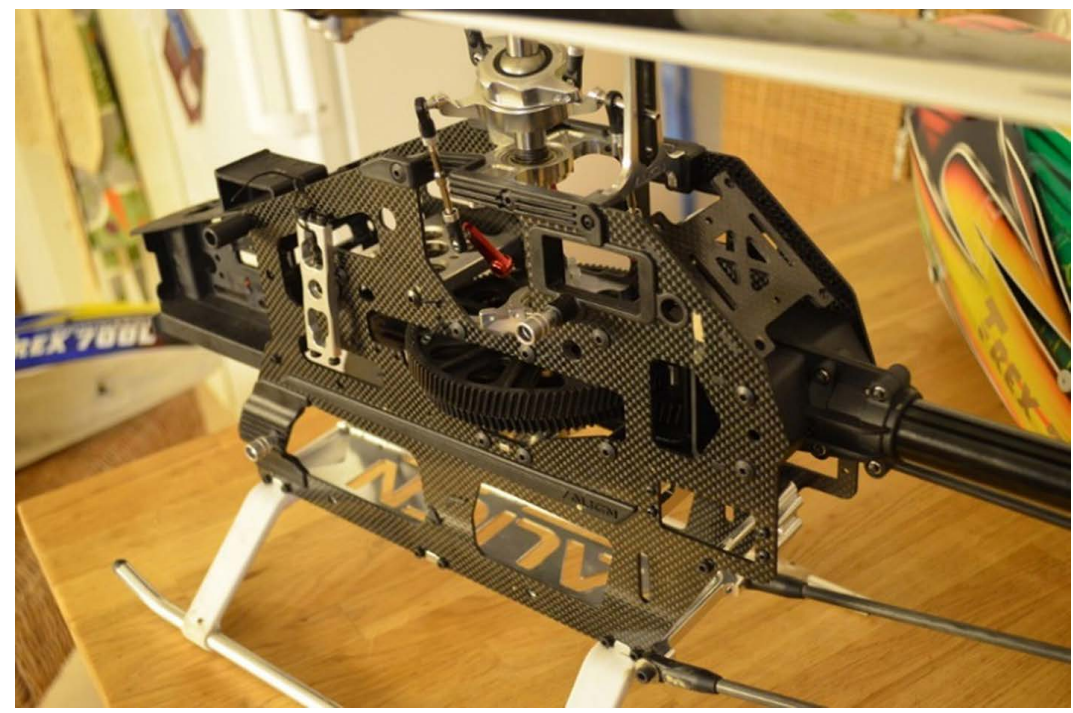

Fig. 3. Off-the-shelf standard Align T-Rex700E airframe. 
In the Fig. 3 the standard T-Rex 700E airframe is presented. For the project purposes most of its features were disadvantages.

The low landing gear left almost no space for cargo, the space for batteries (above landing gear) is very limited and last but not least there is almost no space for additional electronic components due to huge unnecessary plastic element at the front. To prepare this machine for our purposes we needed to completely redesign the frame and arrangement of the components.

\section{DESIGN}

\subsection{Frame modification}

In order to keep same height of the machine and create cargo space underneath we decided to lower the frame and make the landing gear higher. We achieved that by redesigning the main element of the frame. We kept all the necessary openings and removed the part of original frame which was designed to keep the batteries (red rectangle in Fig.4). The modified element is longer in order to keep more electronic element inside and has additional holes for batteries connectors (orange rectangle) which will from now be kept outside the frame. We also created space dedicated for measuring equipment (blue rectangle). This location of measurement equipment in far distance from engine and other electronic devices limits their potentially harmful interference.. We decided to keep original aluminium closing of the frame and moved dedicated mounting cut up (green rectangle), this allowed to use original mounting of the landing gear. The new frame is made of carbon fibre composite with lesser number of openings, so it is much stiffer than the original one.

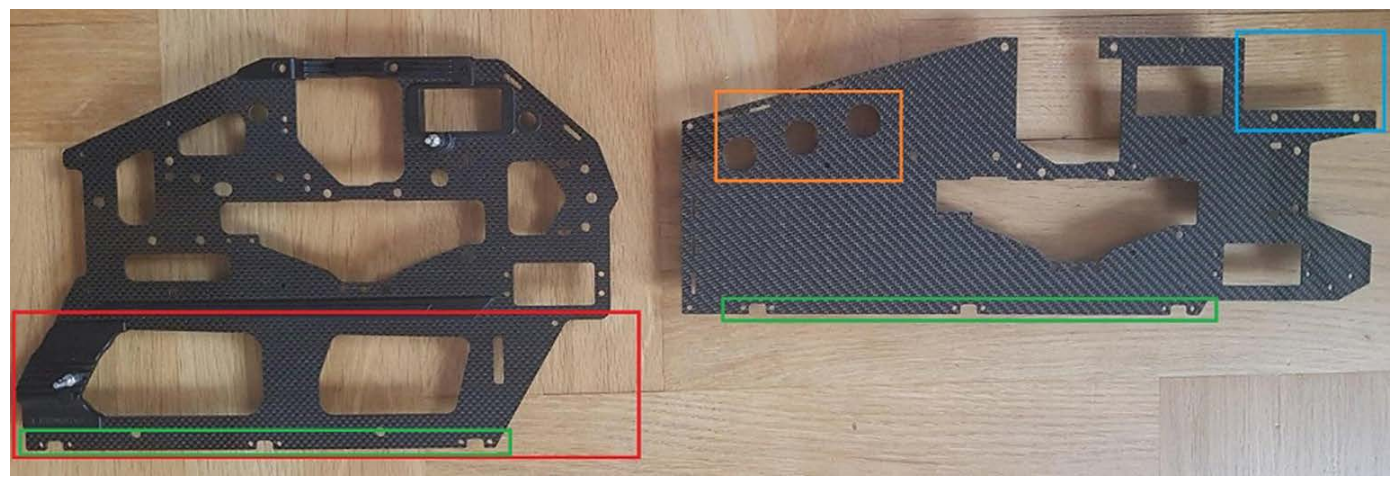

Fig. 4. Original frame (left), modified frame (right).

Due to lack of the helicopter airframe cowling additional elements were designed to close the airframe and cover the electronics within it - Fig. 5 (yellow arrows).

We also had to design a 3D printed elements (blue arrow) to distance one of the servos (purple arrow) and aluminium element (green arrow) necessary for the swash plate to work correctly. 


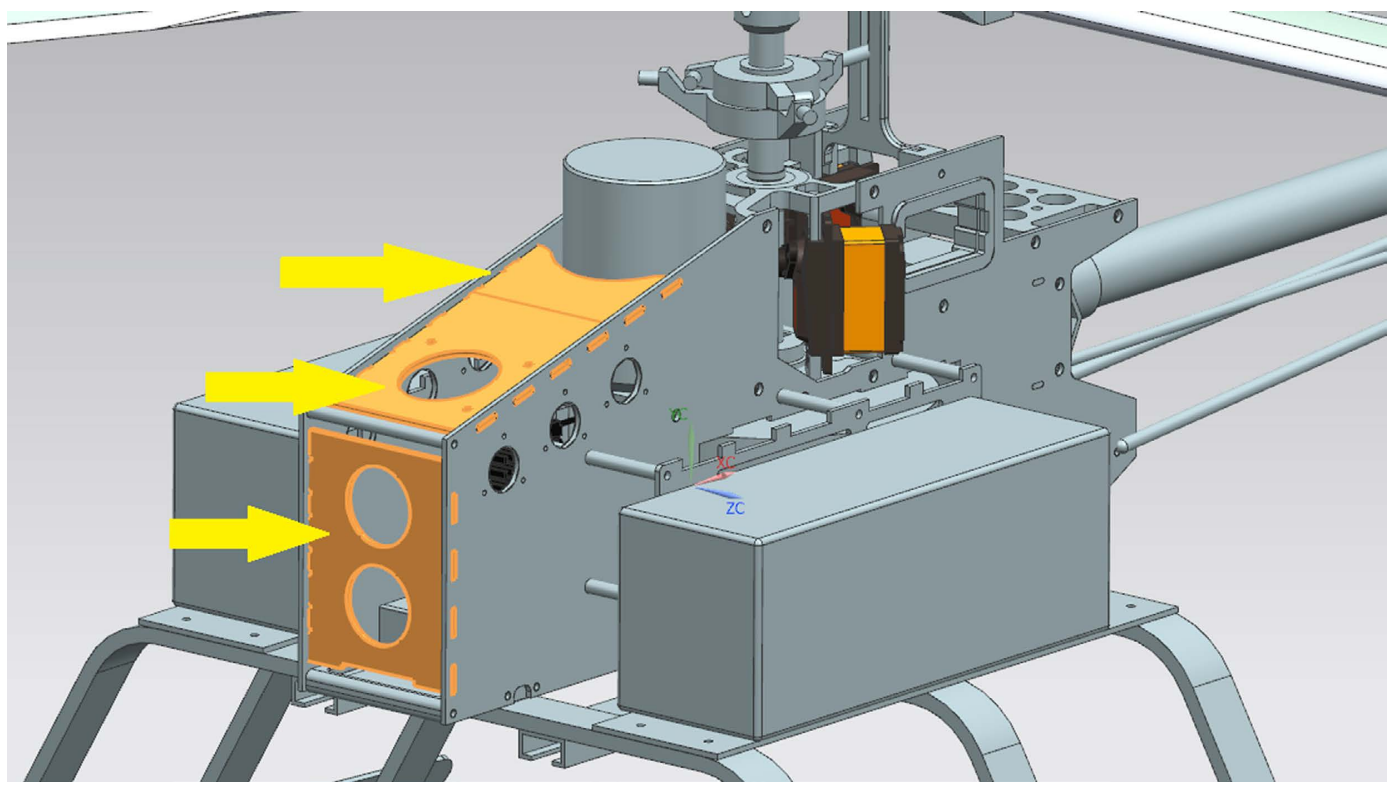

Fig. 5. Closing elements of airframe.

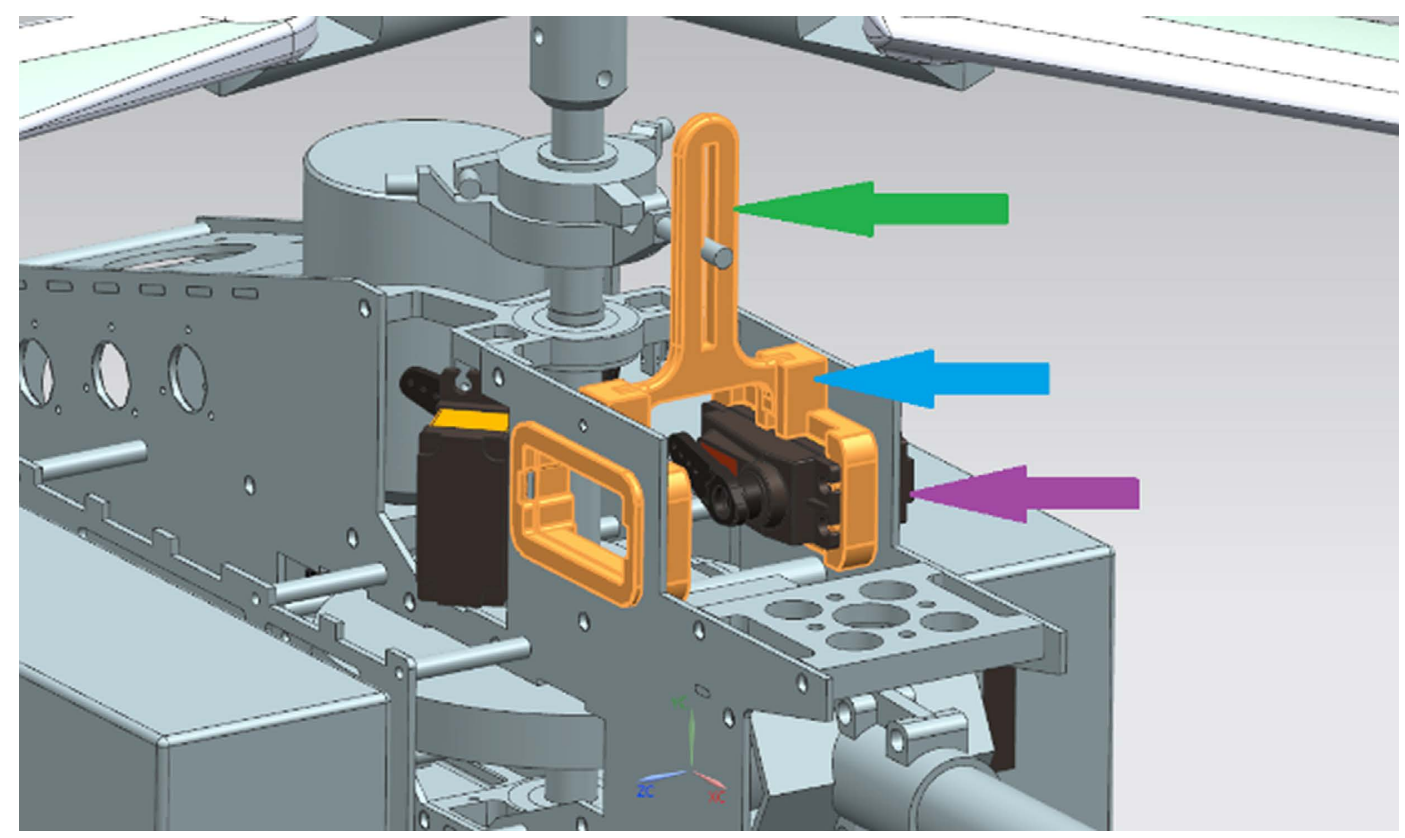

Fig. 6. 3D printed element. 


\subsection{Batteries}

Because batteries now don't have dedicated space inside the frame (which was very narrow allowing only one type of batteries to fit in) they have to be moved somewhere else. We decided it would be best to place them on the sides of helicopter on the same height as the frame on the landing gear. Batteries (blue arrow) have significant weight so to keep moment of inertia as low as possible (makes piloting of the helicopter easier and much more responsive) we wanted to place them as close to the centre of mass as possible. The problem was the main gear (purple arrow) which is much wider than the frame itself. We needed to design spacers (green arrow) between batteries and the frame.

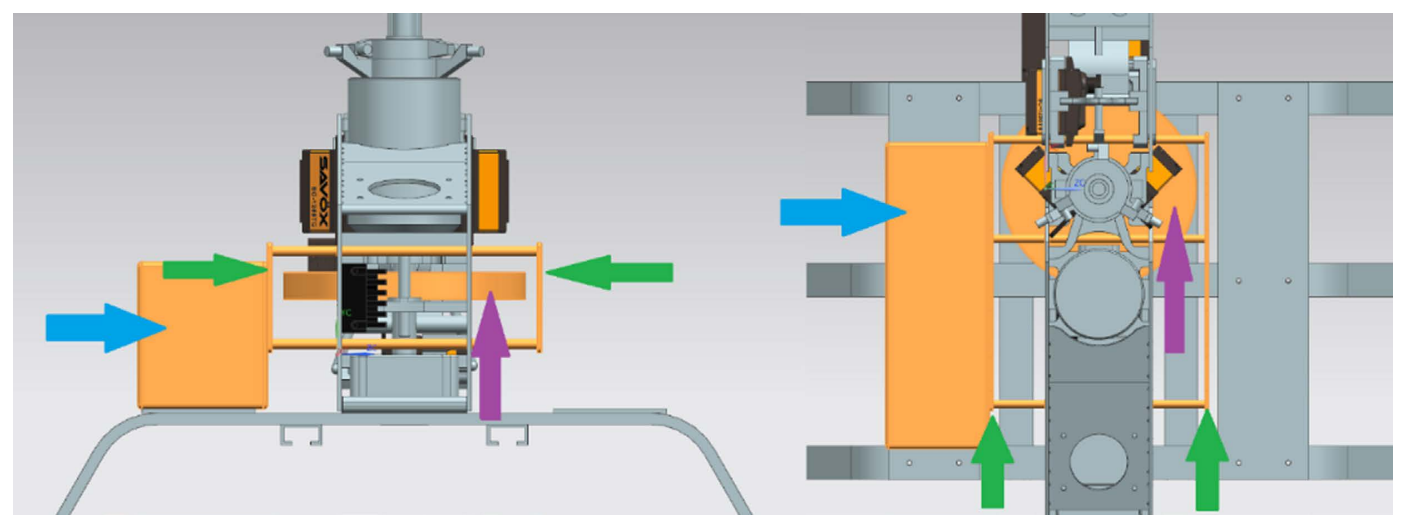

Fig. 7. Spacers of the batteries.

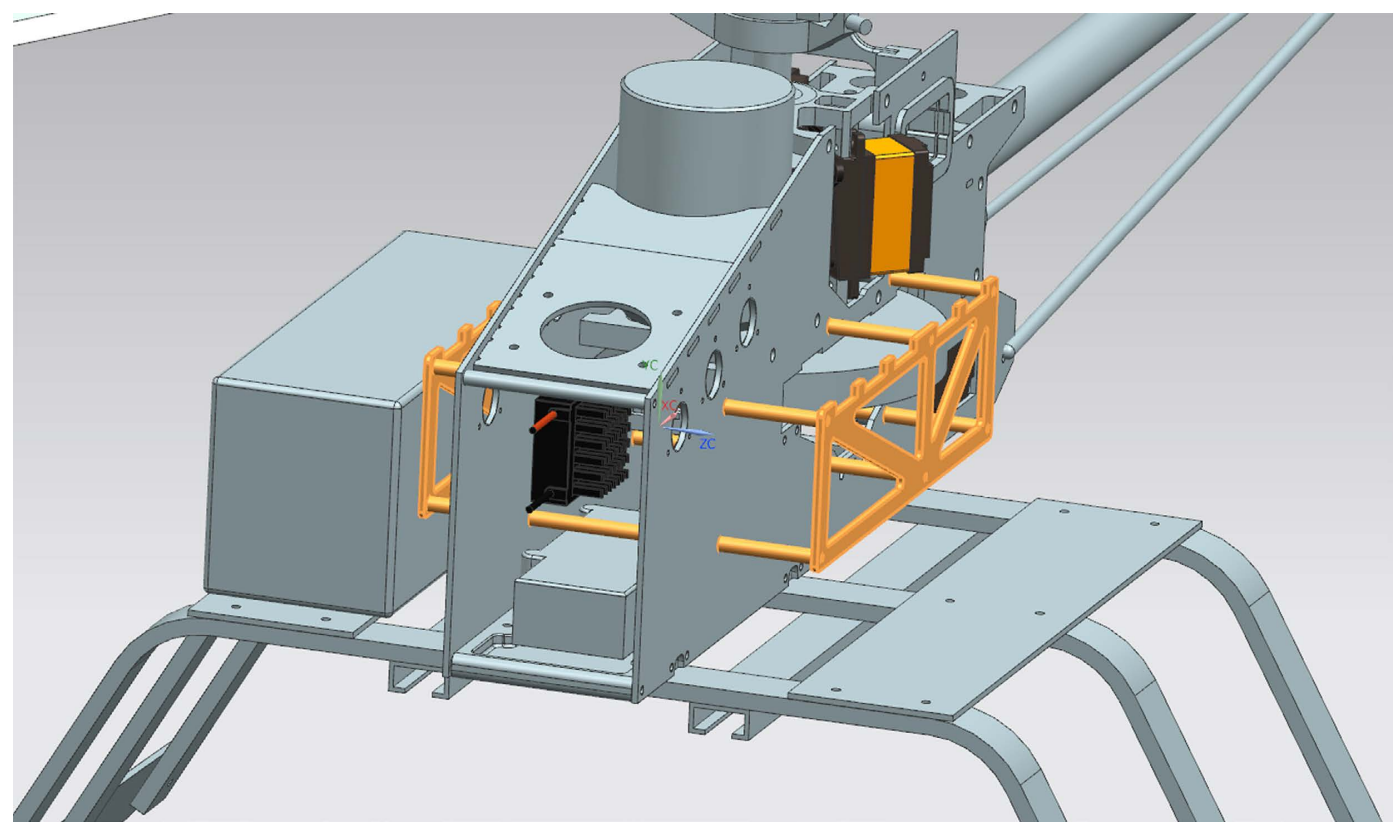

Fig. 8. Spacers of the batteries. 
The spacers are made of carbon plate, just like the frame and the bolts are made of steel, they are going through the frame so the whole construction is firm and solid. Characteristic edging on top of it is made to hold wraps that goes around battery and secure them in place.

\subsection{Landing gear}

There were a lot of demands for the landing gear to be met. First of all it had to be high to create cargo space. Secondly it had to be wide enough to support batteries. Third feature was to protect the body with major components in case of hard landing. It couldn't be too rigid so we decided to make it of aluminium. Normally it only uses two arch but there is a possibility to use third one in case of very heavy cargo. In case of hard landing it might bend a little to absorb the energy and secure expensive components. This arches are very cheap and easy to replace.

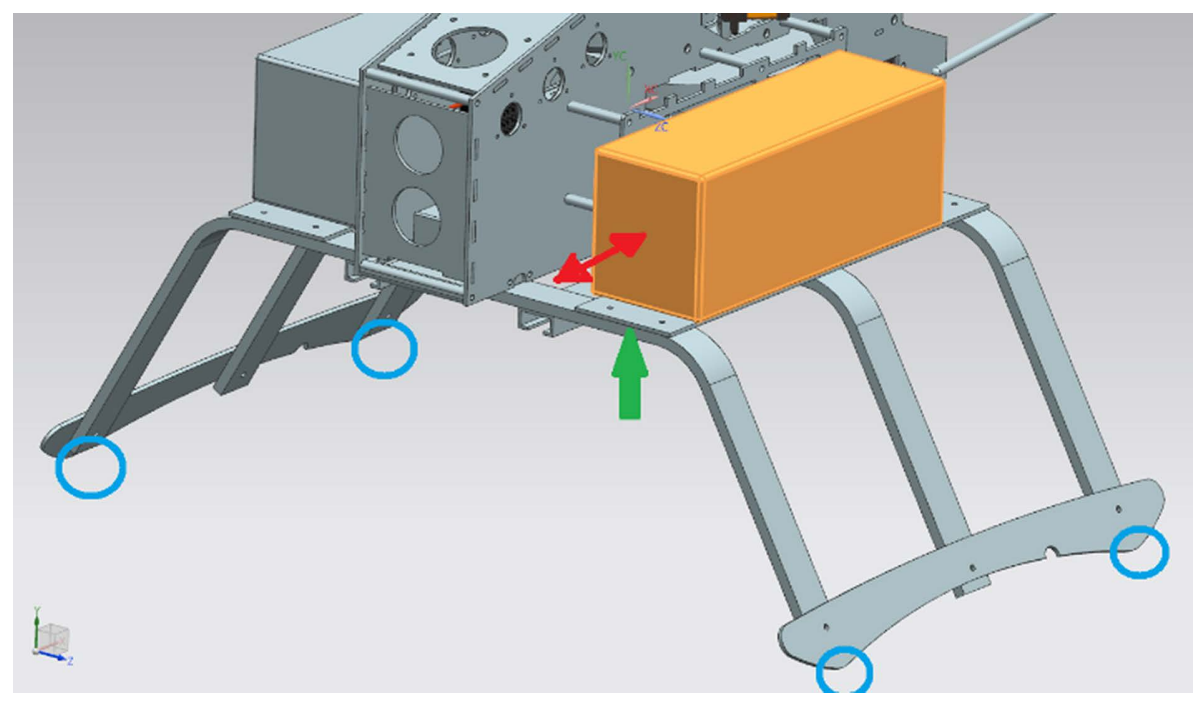

Fig. 9. Landing gear.

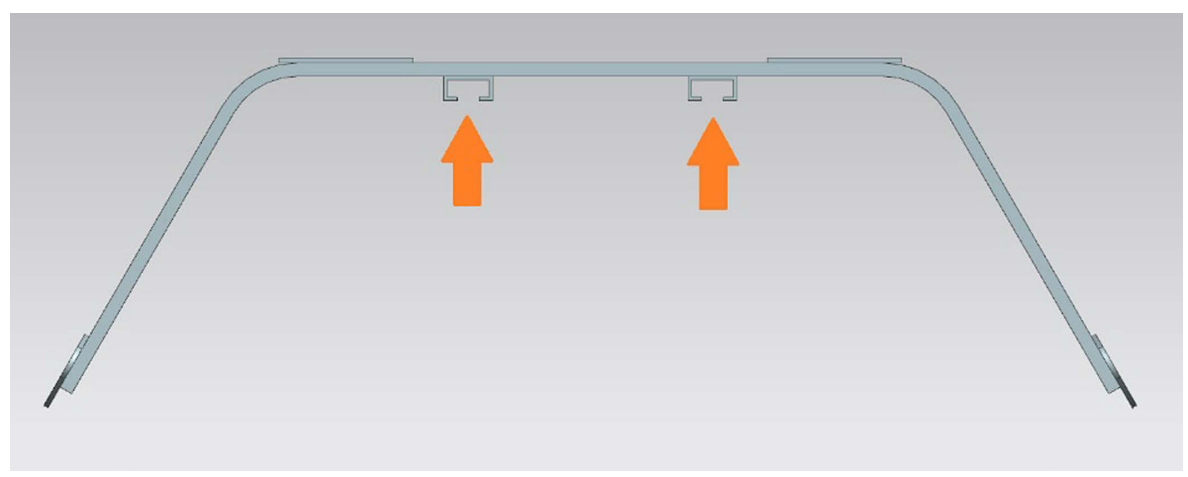

Fig. 10. Landing gear. 
On top of them there are two carbon plates (green arrow) on which the batteries are placed. There is a possibility to move them forward or backward which make manipulating helicopter centre of mass (red arrows) very easy for example in case big cargo is not mounted exactly in rotor axis. Another huge advantage is that batteries of almost any size can be used. Slides are designed to touch the ground in four separate points which makes helicopter much more stable on uneven terrain (blue circles).

There are also two aluminium $\mathrm{C}$-sections (orange arrows) that has been designed to mount the cargo. They are going through whole length of the landing gear so there is possibility to move and lock cargo in any desired position, at the front if it is a camera or at the back in rotor axis.

\subsection{Other changes}

To lower the final cost of the machine and to speed up the process of designing and building RCAC we used components available on the market to upgrade our machine. Here is the list of changes we did:

\begin{tabular}{|c|c|c|}
\hline 1 & Main rotor head & $\begin{array}{l}\text { Original main rotor head has only two blades, in order to increase number } \\
\text { of blades we purchased three blade rotor head dedicated for this model. }\end{array}$ \\
\hline 2 & Tail & $\begin{array}{l}\text { To allow use of longer blades (increase maximum rotor diameter) we } \\
\text { purchased tail upgrade dedicated to this model which allowed using blades } \\
\text { with length up to } 800-840 \mathrm{~mm} \text { (originally it was limited to } 710 \mathrm{~mm} \text {. }\end{array}$ \\
\hline 3 & Tail rotor & $\begin{array}{l}\text { Because in theory best heavy lifting results might be achieved reducing } \\
\text { angular velocity of the main rotor and because tail angular velocity } \\
\text { depends of main rotor angular velocity there was possibility that original } \\
\text { two blade tail rotor head won't be available to generate enough trust to fly } \\
\text { safely. Because of that three blade tail rotor has been purchased. }\end{array}$ \\
\hline 4 & Blades & $\begin{array}{l}\text { To achieve best results in hovering performance we decided to test } 2 \\
\text { different main blades: } \\
\quad \circ \quad \text { Align original } 700 \mathrm{~mm} \text { symmetrical blades ( } 2 \text { blades) } \\
\quad \text { Spinblades } 710 \mathrm{~mm} \text { asymmetrical blades ( } 3 \text { blades) } \\
\text { Additionally we also purchased asymmetrical tail blades to increase tail } \\
\text { rotor thrust. }\end{array}$ \\
\hline 5 & Batteries & $\begin{array}{l}\text { We used a pair of 6-cell batteries (12S configuration) with capacity of } \\
10000 \mathrm{mAh} \text { instead of stock batteries with capacity of } 5800 \mathrm{mAh}\end{array}$ \\
\hline 6 & Engine & $\begin{array}{l}\text { To lower main rotor velocity ratio we decided to purchase another engine, } \\
\text { with lower kV (motor velocity constant measured in RPM per volt ratio. } \\
\text { We decided to buy KDE700XF-295-G3 brushless motor. Thanks to that } \\
\text { we were able to achieve main rotor velocity speeds from } 900 \text { up to } \\
\text { 1150RPM. With original engine it is possible to get from } 1430 \text { up to } \\
\text { 1900RPM. Having this two engines available it was possible to test main } \\
\text { rotors in wider angular velocity range. }\end{array}$ \\
\hline 7 & $\mathrm{BEC}$ & $\begin{array}{l}\text { We decided to upgrade stock BEC (Battery Elimination Circuit, it allows } \\
\text { to power receiver from the same battery that powers engine and servos) } \\
\text { because we was afraid it might fail during demanding tests we planned. } \\
\text { We decided to use Castle Creations BEC-PRO, which is able to handle up } \\
\text { to } 50 \mathrm{~V} \text {. }\end{array}$ \\
\hline 8 & Servos & $\begin{array}{l}\text { Because we was planning significantly increasing payload we knew that } \\
\text { servos will have to deal with the great amount of additional force so we } \\
\text { also had to replace the stock one to a much more durable. We decided to } \\
\text { buy Savox SC-1258T Servos. }\end{array}$ \\
\hline
\end{tabular}




\section{THE FINAL ASSEMBLY}

In the Fig. 11 the final assembly of the RCAC helicopter is shown.

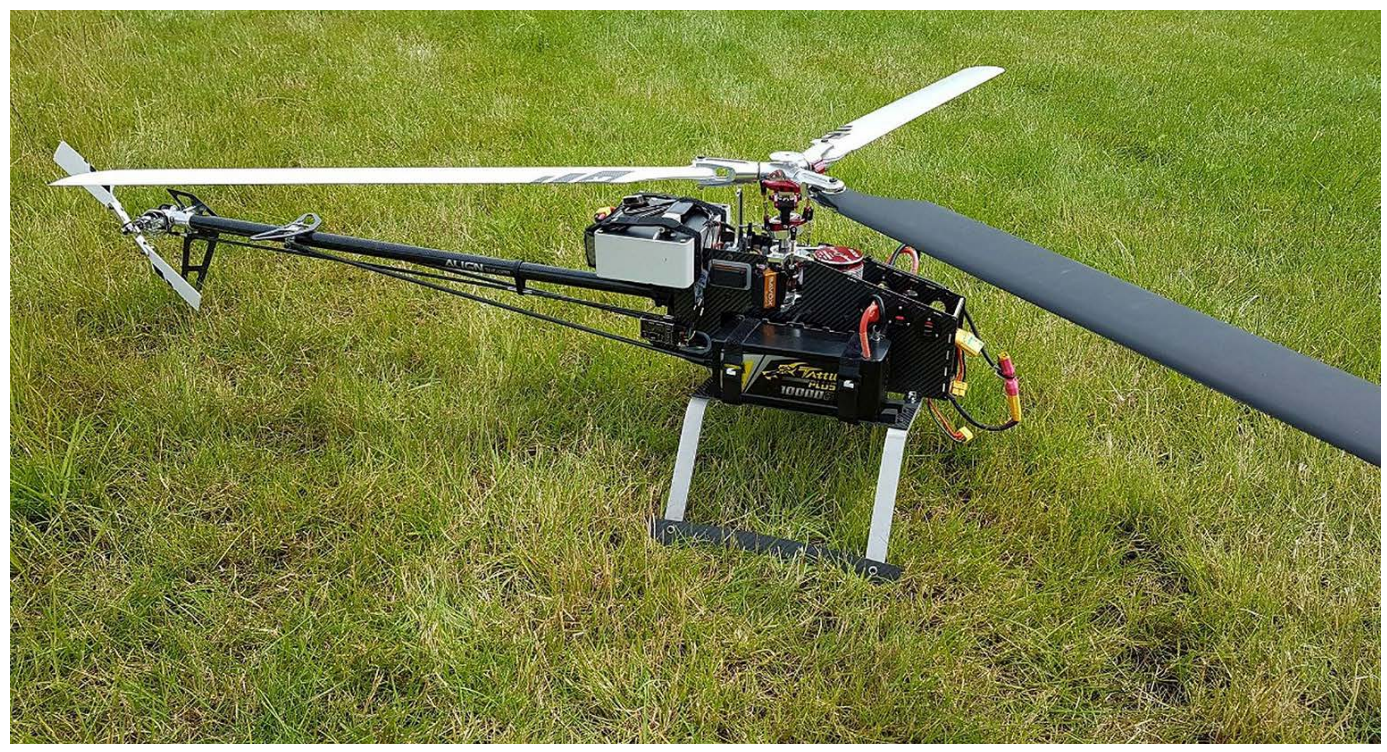

Fig. 11. The RCAC helicopter with three-bladed rotor.

Main differences between original model and modified one has been summarised in table:

\begin{tabular}{|l|c|c|}
\hline & Trex 700E DFC PRO & RCAC \\
\hline Measures & & 360 \\
\hline Hight [mm] & 360 & 1245 \\
\hline Length [mm] & 1350 & 448 \\
\hline Width [mm] & 208 & \\
\hline Weight [g] & 3100 & 4650 \\
\hline With 2x Align 700 blades (no batteries) & - & 4700 \\
\hline With 2x Spinblades 710 blades (no batteries) & - & 5100 \\
\hline With 3x Spinblades 710 blades (no batteries) & 1780 & 3000 \\
\hline Batteries & - & 450 \\
\hline Measuring equipment & & $850-1900$ \\
\hline Main rotor & $1430-1900$ & 1800 \\
\hline Angular velocity [RPM] & 1600 & 820 \\
\hline Max. diameter [mm] & 710 & 281 \\
\hline Max blade length [mm] & & \\
\hline Tail rotor & 281 & $140 \times 240 \times 240$ \\
\hline Max. diameter & & $70 \times 80 \times 200$ \\
\hline Other & $0 \times 0 \times 0$ & \\
\hline Cargo space (height, length, width) [mm] & Yes & No \\
\hline $\begin{array}{l}\text { Space for measuring equipment (height, length, } \\
\text { width) [mm] }\end{array}$ & & \\
\hline Limited space for battery & & \\
\hline
\end{tabular}




\section{IN-FLIGHT TESTS}

The modified helicopter was tested in different configurations (109 configurations, Fig. 12) including: different main rotor heads, different main blades, different engines, different angular velocities and different cargo up to $10 \mathrm{~kg}$. During this tests machine was working seamlessly and has proven to have all main key features it has been designed to have.

\begin{tabular}{|c|c|c|c|c|c|c|c|c|c|c|c|c|}
\hline \multirow{2}{*}{ Rotor configuration } & \multirow{2}{*}{$\begin{array}{c}\text { Angular } \\
\text { velocity }[\mathrm{rpm}]\end{array}$} & \multicolumn{11}{|c|}{ Additional weight [kg] } \\
\hline & & 0 & 1 & 2 & 3 & 4 & 5 & 6 & 7 & 8 & 9 & 10 \\
\hline \multirow{3}{*}{ 2x Align 700} & 1600 & & & & & & & & & & & \\
\hline & 1700 & & & & & & & & & & & \\
\hline & 1800 & & & & & & & & & & & \\
\hline \multirow{3}{*}{ 2x Spinblades 710} & 1600 & & & & & & & & & & & \\
\hline & 1700 & & & & & & & & & & & \\
\hline & 1800 & & & & & & & & & & & \\
\hline \multirow{8}{*}{ 3x Spinblades 710} & 1100 & & & & & & & & & & & \\
\hline & 1200 & & & & & & & & & & & \\
\hline & 1300 & & & & & & & & & & & \\
\hline & 1430 & & & & & & & & & & & \\
\hline & 1500 & & & & & & & & & & & \\
\hline & 1600 & & & & & & & & & & & \\
\hline & 1700 & & & & & & & & & & & \\
\hline & 1800 & & & & & & & & & & & \\
\hline
\end{tabular}

Fig. 12. Tested configurations of RCAC helicopter

Due to the limitations of the project it was not possible to test the different rotor configurations in the wind-tunnel. It was decided that the performance of the rotors will be measured during open space flights in hovering conditions. During the tests power required was measured for various rotor configurations (number of blades, blades type), various rotor angular speeds, and various take-off masses. The power was measured by the Electronic Speed Controller. In Fig. 13 the comparison of powers required for three different rotors is presented.

First conclusion from the flight tests is that, the measurements are not very accurate. Although the care was taken to fly only in no wind conditions some wind gust were present which can be clearly seen in some of the plots. Any horizontal wind decreases the power required - such was the probable cause of the first point of the 2 A rotor plot. Unfortunately, due to weather conditions and project time restrictions it was not possible to repeat the test several times.

From the Fig. 13 it can be noticed, that the performance of the standard rotor (2A) can be easily improved by using the Spinblades asymmetrical blades. However, of course, using three blades with the same high RPMs leads to increase of the power required.

Another comparison is shown in the Fig. 14. Here, the best, achieved in the tests, performance of each rotor is compared. 


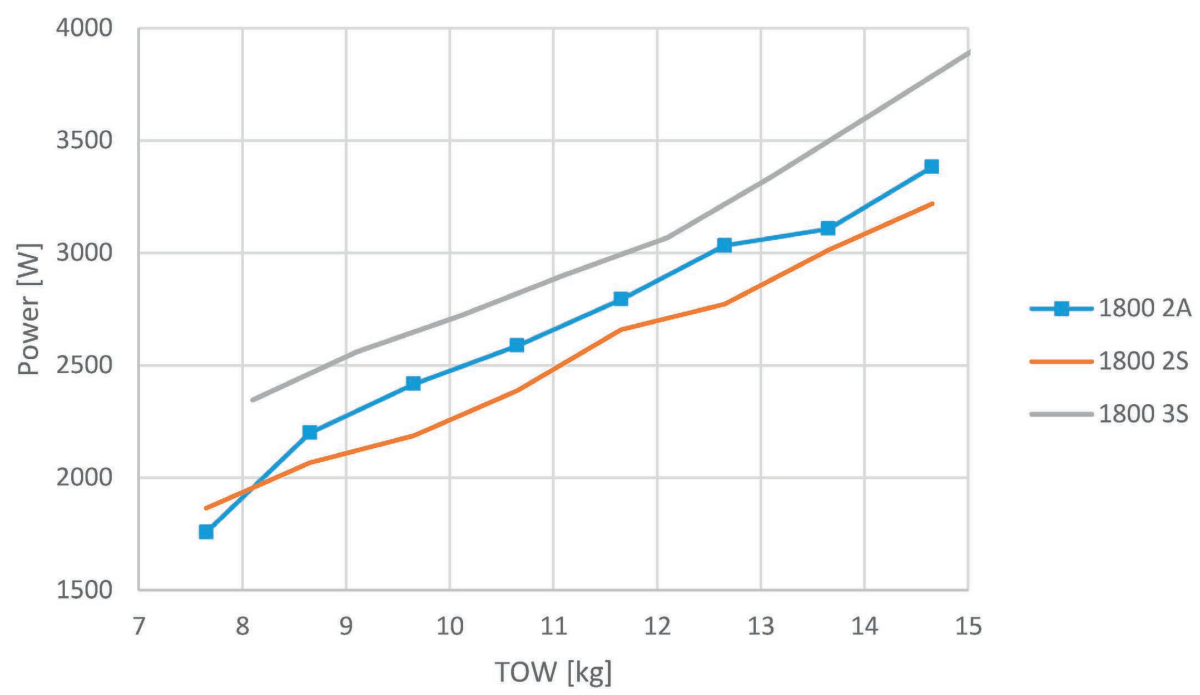

Fig. 13. Power required vs. take-off weight. Rotors angular speed 1800RPM, three different rotors (2A -2 blades, Align 700, 2S - 2 blades, Spinblades 710, 3S -3 blades, Spinblades 710).

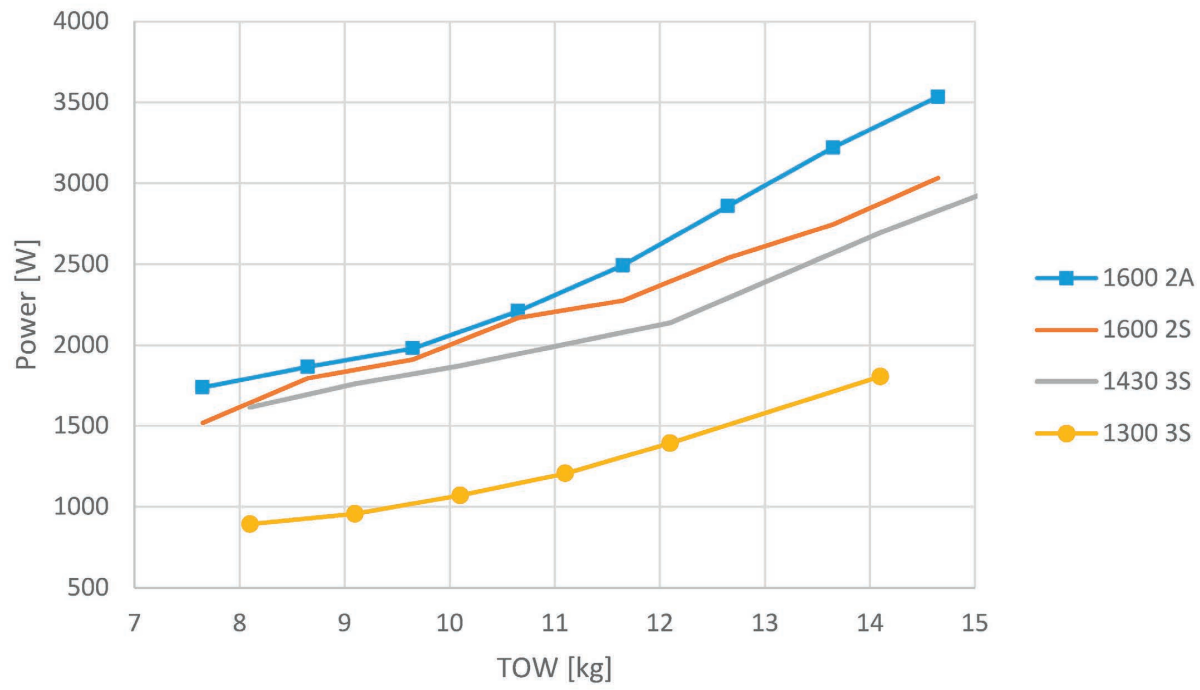

Fig. 14. Best performance of three rotors.

For the 3S rotor there are two curves shown - for 1430 and 1300 RPMs. It can be noticed, that lowering the main rotor RPMs leads to decrease of the power required for hover. Of course there are some limits of the performance. In our case the helicopter performance was limited by two causes: the motors' Electronic Speed Controller which was overheated when carrying heavy payloads and tail rotor performance, which was not enough to keep helicopter stable at the very low RPMs. In this comparison it can be noticed, that the best performance is achieved with the low-rpm three-bladed main rotor with asymmetrical blades. 


\section{PERFORMANCE}

Overall performance of modified helicopter was more than good, to prove that we decided to compare it with Vario V2 which is a helicopter designed specifically to carry cameras (Fig. 15). Our T-Rex 700E RCAC modification have similar performance even though it is two times smaller and lighter.

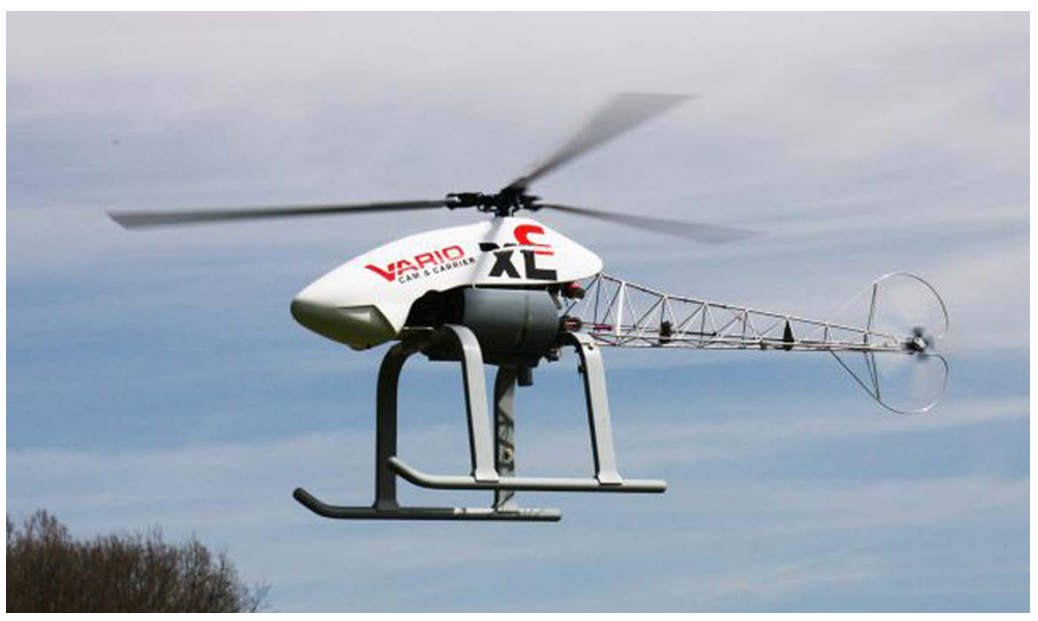

Fig. 15. Vario V2, helicopter with similar features to modified T-Rex 700E RCAC.

\begin{tabular}{|c|c|c|}
\cline { 2 - 3 } \multicolumn{1}{|c|}{} & Vario V2 & RCAC \\
\hline Length [mm] & 2450 & 1245 \\
\hline Hight [mm] & 700 & 360 \\
\hline Width [mm] & 1000 & 448 \\
\hline Rotor diameter [mm] & 2500 & 1800 \\
\hline Helicopter weight (no fuel/batteries, cargo) [kg] & 17 & 8.1 \\
\hline Max weight of fuel/batteries + cargo [kg] & 15 & 13 \\
\hline Max take-off weight [kg] & 32 & 21.1 \\
\hline Helicopter weight to max TOW ratio & $113 \%$ & $62 \%$ \\
\hline Type of engine & Turbine & Electric motor \\
\hline Angular velocity [rpm] & $850-1700$ & $1100-1800$ \\
\hline Max durability of flight [min.] & 45 & 37 \\
\hline
\end{tabular}

Fig. 16. Comparison between Vario V2 and T-Rex 700E RCAC.

\section{CONCLUSIONS}

We managed to successfully redesign whole interior structure of the standard Align T-Rex 700E electric helicopter making it much useful for research. It is now capable of carrying significant weights, up to $10 \mathrm{~kg}$, has big cargo space. It is compatible with almost every set of batteries 
and has dedicated space for measuring equipment. We believe it is a great research machine which might be used to test different components, thanks to its compatibility with wide variety of them and for tasks like carrying big cargos like measuring equipment. It is a great base for future develop and tests.

\section{ACKNOWLEDGEMENTS}

We would like to express deep gratitude to Lockheed Martin Co. for sponsoring this project and to Faculty of Power and Aeronautical Engineering of the Warsaw University of Technology for supervision for the whole duration of it.

\section{REFERENCES}

[1] Cameron D. Robertson and Todd M. Reichert. „Design and Development of the Atlas Human-Powered Helicopter”, AIAA Journal, Vol. 53, No. 1 (2015), pp. 20-32.

[2] Alfred Gessow, Garry C. Myers Jr. "Aerodynamics of the Helicopter” 1952.

[3] F.B. Gustafson and Alfred Gessow "Effect of rotor-tip speed on helicopter hovering performance and maximum forward speed" 1946.

\section{PROJEKT I BUDOWA UDŹWIGOWEJ WERSJI ŚMIGLOWCA ZDALNIE STEROWANEGO}

\section{Streszczenie}

Artykuł niniejszy prezentuje modyfikację do wersji udźwigowej zdalnie sterowanego śmigłowca T-REX 700 PRO DFC, oryginalnie zbudowanego do akrobacji lotniczych. Celem powstania modyfikacji jest zapotrzebowanie na tanie i niezawodne maszyny bezzałogowe do przenoszenia ładunków zarówno dla celów badawczych jak i komercyjnych. Konstrukcja zmodyfikowanego śmigłowca umożliwia przenoszenie aparatury pomiarowej, modułów dodatkowych (np. autopilota) i ładunków. Maszyna ta może być również użyta jako stanowisko testowe dla wirników nośnych i innych podzespołów. Aby spełnić te wymagania rama nośna śmigłowca oraz podwozie zostały przeprojektowane z wykorzystaniem technik $\mathrm{CAD} / \mathrm{CAM} / \mathrm{CAE}$ aby zapewnić uzyskanie odpowiednich przestrzeni ładunkowych oraz właściwe rozmieszczenie wyposażenia. Dodatkowo belka ogonowa została wydłużona, co pozwala na zastosowanie dłuższych łopat wirnika nośnego. Wykonane zmiany doprowadziły do znacznego powiększenia przenoszonego ładunku użytecznego. Zaprojektowane elementy zostały wykonane i przebudowany śmigłowiec został przetestowany w locie. Podczas prób mierzone były podstawowe parametry osiągowe śmigłowca.

Słowa kluczowe: śmigłowiec, wirnik, modyfikacja. 